\title{
Association between $I L-10$ genetic variations and cervical cancer susceptibility in a Chinese population
}

\author{
C.Y. Bai, X.Y. Shi, J. He, J. Xue and Y. Feng \\ Department of Gynecology, Affiliated Hospital of Yanan University, Yan'an, \\ China \\ Corresponding author: X.Y. Shi \\ E-mail: shuxiaoyany@163.com \\ Genet. Mol. Res. 15 (3): gmr.15038116 \\ Received November 25, 2015 \\ Accepted January 15, 2016 \\ Published August 5, 2016 \\ DOI http://dx.doi.org/10.4238/gmr.15038116
}

Copyright (C) 2016 The Authors. This is an open-access article distributed under the terms of the Creative Commons Attribution ShareAlike (CC BY-SA) 4.0 License.

\begin{abstract}
We conducted an investigation into the role of the $I L$ 10 polymorphisms $-592 \mathrm{~A} / \mathrm{C}$ ( $\mathrm{rs} 1800872),-819 \mathrm{C} / \mathrm{T}$ (rs1800871), and $-1082 \mathrm{~A} / \mathrm{G}$ (rs1800896) in cervical cancer risk in a Chinese population. A case-control study was carried out, including 165 newly diagnosed cervical cancer patients and 165 control subjects. The polymerase chain reaction-restriction fragment length polymorphism method was used to genotype the three $I L-10$ variant loci. Using conditional logistic regression analysis, we observed that homozygous $I L-10-819 \mathrm{C} / \mathrm{T}$ TT carriers were at significantly increased risk of cervical cancer compared to homozygous $\mathrm{CC}$ individuals, with an adjusted odds ratio (OR) of 2.23 and a $95 \%$ confidence interval (CI) of 1.16-4.30. Moreover, the $\mathrm{CT}+\mathrm{TT}$ genotype was significantly associated with cervical cancer in comparison to the wild-type variant $(\mathrm{OR}=1.69,95 \% \mathrm{CI}=1.04-2.76$; $\mathrm{P}=0.03$ ). In conclusion, our study suggests that the $I L-10-819 \mathrm{C} / \mathrm{T}$
\end{abstract}

Genetics and Molecular Research 15 (3): gmr.15038116 
genetic variation may contribute to cervical cancer risk in the Chinese population examined.

Key words: Interleukin-10; Polymorphism; Cervical cancer

\section{INTRODUCTION}

Cervical cancer is the third most common malignancy among women, with an estimated global incidence of over 500,000 new cases per year (Siegel et al., 2012). The etiology of this disease has been widely studied, and previous research has demonstrated that infection with human papillomavirus (HPV) contributes to its development (Woodman et al., 2001; Duenas-Gonzalez et al., 2014). Moreover, risk factors are reported to include having multiple sexual partners, sexual intercourse under 16 years of age, multiple pregnancies, and multiparity (Memiah et al., 2015; Rigaud, 2015). Moreover, previous studies have reported that many genes play an important role in cervical cancer risk, including $C X C L 12, T N F-\alpha$, $m i R-146 a, m i R-143$, miR-145, MMP-9, and CD192 (Chen et al., 2015; Xie et al., 2015; Yin et al., 2015; Zhang et al., 2015).

Interleukin-10 (IL-10) can inhibit the synthesis of other cytokines such as IL-6, IL- $1 \beta$, IL- $1 \alpha$, and tumor necrosis factor- $\alpha$ in activated macrophages, and interferon- $\gamma$ in T cells (D'Andrea et al., 1993). Previous studies have revealed that HPV infection is associated with elevated expression of $I L-10$ in cervical tissue (Torres-Poveda et al., 2012). It has been reported that variation in the $I L-10$ gene can influence expression of the corresponding protein, and thus may affect its role in cervical carcinogenesis (Turner et al., 1997; Roh et al., 2002). In our study, we assessed the influence of the $I L-10$ polymorphisms -592A/C (rs1800872), -819C/T (rs1800871), and -1082A/G (rs1800896) on cervical cancer risk in a Chinese population.

\section{MATERIAL AND METHODS}

\section{Patients}

A case-control study was carried out, including 165 newly diagnosed cervical cancer patients and 165 control subjects. All participants were recruited from the Affiliated Hospital of Yanan University between January 2013 and December 2014. Cervical cancer patients were diagnosed by biopsy or resected tissue examined by two pathologists.

Control subjects, all of whom were selected from individuals attending the hospital for a regular gynecological examination, were matched to patients by age ( \pm 5 years). Those with a history of tumors, or serious infectious or gynecological diseases were excluded from our study. The present study was approved by the Ethics Committee of the Affiliated Hospital of Yanan University, and was performed based on the Declaration of Helsinki. Informed consent was obtained from each study subject.

Each patient and control subject was interviewed regarding demographic and lifestyle characteristics using a self-designed questionnaire including the following information: age, age at first sexual intercourse, age at menarche, body mass index (BMI), lifetime number of sexual partners, HPV-16 or -18 infection status, and family history of cancer.

Genetics and Molecular Research 15 (3): gmr.15038116 


\section{Genotyping method}

A venous blood sample $(5 \mathrm{~mL})$ was obtained for DNA extraction from each subject after enrollment into this study. Genomic DNA was extracted from collected peripheral blood with a TIANamp Blood DNA Kit (TIANGEN, Beijing, China) following the manufacturer protocol. A polymerase chain reaction (PCR)-restriction fragment length polymorphism assay was conducted to detect $I L-10-592 \mathrm{~A} / \mathrm{C}$ (rs1800872), -819C/T (rs1800871), and -1082A/G (rs1800896) genotypes. The primers and restriction enzymes used are shown in Table 1 . The PCR cycling conditions were as follows: $95^{\circ} \mathrm{C}$ for $10 \mathrm{~min}$, then 35 cycles of $95^{\circ} \mathrm{C}$ for $30 \mathrm{~s}$, $62^{\circ} \mathrm{C}$ for $30 \mathrm{~s}$, and $72^{\circ} \mathrm{C}$ for $30 \mathrm{~s}$, followed by $72^{\circ} \mathrm{C}$ for $10 \mathrm{~min}$.

\begin{tabular}{|c|c|c|c|}
\hline$I L-10$ & SNP & Primers & Restriction enzyme \\
\hline$-592 \mathrm{~A} / \mathrm{C}$ & rs1800872 & $\begin{array}{l}\text { 5'-AATGAGCACTAGGTGACTAGC-3' } \\
\text { 5'-CCTACCTCTCTGAGACGTAA-3' }\end{array}$ & $R s a \mathrm{I}$ \\
\hline$-819 \mathrm{C} / \mathrm{T}$ & rs1800871 & $\begin{array}{l}\text { 5'-GCTTCTCCTATGCTAGTCAGGTA-3' } \\
\text { 5'-TGGTCTCAAGTGGGTAAGAGT-3' }\end{array}$ & MseI \\
\hline$-1082 \mathrm{~A} / \mathrm{G}$ & rs 1800896 & $\begin{array}{l}\text { 5'-AGAAGTCCTGATGTCACTGC-3' } \\
\text { 5'-AAGTCAGGATTCCATGGAG-3' }\end{array}$ & MnlI \\
\hline
\end{tabular}

$\mathrm{SNP}=$ single nucleotide polymorphism.

\section{Statistical analysis}

Comparisons of baseline information between the two groups was carried out using the chi-square test and the Student $t$-test. Associations between genetic polymorphisms and cervical cancer risk were analyzed using conditional regression analysis, and odds ratios (ORs) and corresponding 95\% confidence intervals (CIs) were obtained. The Stata version 9.0 statistical software (StataCorp., College Station, TX, USA) was employed to analyze results, and $\mathrm{P}$ values less than 0.05 were considered to represent a statistically significant difference.

\section{RESULTS}

The demographic and lifestyle characteristics of the study subjects are reported in Table 2. The mean ages of patients and controls were $42.55 \pm 9.46$ and $40.94 \pm 10.42$ years, respectively. In comparison to healthy controls, cervical cancer patients were younger at the time of first sexual intercourse $(t=6.40, \mathrm{P}<0.001)$ and were more likely to be infected with HPV-16 or -18 (chi-square $=91.80, \mathrm{P}<0.001$ ). However, no significant difference was found for BMI $(t=0.41, \mathrm{P}=0.34)$, age at menarche $(t=0.80, \mathrm{P}=0.21)$, lifetime number of sexual partners $(t=1.92, \mathrm{P}=0.38)$, or family history of cancer $(t=1.12, \mathrm{P}=0.29)$.

We then analyzed the distributions of $I L-10-592 \mathrm{~A} / \mathrm{C},-819 \mathrm{C} / \mathrm{T}$, and $-1082 \mathrm{~A} / \mathrm{G}$ genotypes among cervical cancer patients and control subjects (Table 3 ). The chi-square test revealed no significant difference in AA, AC, and CC $-592 \mathrm{~A} / \mathrm{C}$ genotype frequencies between these two groups (chi-square $=1.11, \mathrm{P}=0.58$ ). Using conditional logistic regression analysis, we observed that homozygous $I L-10-819 \mathrm{C} / \mathrm{T}$ TT carriers demonstrated a significantly increased risk of cervical cancer when compared to homozygous CC individuals, with an adjusted OR (and 95\% CI) of 2.23 (1.16-4.30). Moreover, the CT+TT genotype was significantly associated with cervical cancer in comparison to the wild-type variant $(\mathrm{OR}=1.69,95 \% \mathrm{CI}=1.04-2.76 ; \mathrm{P}=0.03)$.

Genetics and Molecular Research 15 (3): gmr.15038116 
Table 2. Demographic and lifestyle characteristics of study subjects.

\begin{tabular}{|c|c|c|c|c|c|c|}
\hline Variable & Patients & $\%$ & Controls & $\%$ & Chi-square test or $t$-test & $\mathrm{P}$ value \\
\hline Age (mean, years) & $42.55 \pm 9.46$ & & $40.94 \pm 10.42$ & & 1.47 & 0.07 \\
\hline Age at first sexual intercourse (years) & $16.42 \pm 6.84$ & & $20.55 \pm 4.69$ & & 6.40 & $<0.001$ \\
\hline $\mathrm{BMI}\left(\mathrm{kg} / \mathrm{m}^{2}\right)$ & $24.20 \pm 3.51$ & & $24.05 \pm 3.20$ & & 0.41 & 0.34 \\
\hline Age at menarche (years) & $12.67 \pm 1.76$ & & $12.82 \pm 1.64$ & & 0.80 & 0.21 \\
\hline \multicolumn{7}{|l|}{ Lifetime number of sexual partners } \\
\hline$\leq 3$ & 132 & 80.00 & 141 & 85.45 & & \\
\hline $4-9$ & 29 & 17.58 & 22 & 13.33 & & \\
\hline$>9$ & 4 & 2.42 & 2 & 1.21 & 1.92 & 0.38 \\
\hline \multicolumn{7}{|l|}{ HPV-16 or -18 infection } \\
\hline Negative & 41 & 24.85 & 128 & 77.58 & & \\
\hline Positive & 124 & 75.15 & 37 & 22.42 & 91.80 & $<0.001$ \\
\hline \multicolumn{7}{|l|}{ Family history of cancer } \\
\hline No & 144 & 87.27 & 150 & 90.91 & & \\
\hline Yes & 21 & 12.73 & 15 & 9.09 & 1.12 & 0.29 \\
\hline
\end{tabular}

$\mathrm{BMI}=$ body mass index; HPV = human papillomavirus.

Table 3. Association between $I L-10$ genetic variations and development of cervical cancer.

\begin{tabular}{|c|c|c|c|c|c|c|c|c|c|}
\hline Genotype & Patients & $\%$ & Controls & $\%$ & Chi-square & $\mathrm{P}$ & $\mathrm{P}$ for HWE & OR $(95 \% \mathrm{CI})^{1}$ & $\mathrm{P}$ \\
\hline \multicolumn{10}{|l|}{$-592 \mathrm{~A} / \mathrm{C}$} \\
\hline AA & 63 & 38.18 & 70 & 42.42 & & & & 1.0 (Ref.) & - \\
\hline $\mathrm{AC}$ & 82 & 49.70 & 80 & 48.48 & & & & $1.14(0.70-1.85)$ & 0.58 \\
\hline $\mathrm{CC}$ & 20 & 12.12 & 15 & 9.09 & 1.11 & 0.58 & 0.24 & $1.48(0.66-3.39)$ & 0.30 \\
\hline $\mathrm{AC}+\mathrm{CC}$ & 102 & 61.82 & 95 & 57.58 & & & & $1.19(0.75-1.90)$ & 0.43 \\
\hline \multicolumn{10}{|l|}{$-819 \mathrm{C} / \mathrm{T}$} \\
\hline $\mathrm{CC}$ & 45 & 27.27 & 64 & 38.79 & & & & 1.0 (Ref.) & - \\
\hline $\mathrm{CT}$ & 76 & 46.06 & 73 & 44.24 & & & & $1.48(0.87-2.52)$ & 0.12 \\
\hline TT & 44 & 26.67 & 28 & 16.97 & 6.93 & 0.03 & 0.36 & $2.23(1.16-4.30)$ & 0.01 \\
\hline $\mathrm{CT}+\mathrm{TT}$ & 120 & 72.73 & 101 & 61.21 & & & & $1.69(1.04-2.76)$ & 0.03 \\
\hline \multicolumn{10}{|l|}{$-1082 \mathrm{~A} / \mathrm{G}$} \\
\hline $\mathrm{AA}$ & 74 & 44.85 & 80 & 48.48 & & & & 1.0 (Ref.) & - \\
\hline $\mathrm{AG}$ & 75 & 45.45 & 72 & 43.64 & & & & $1.13(0.70-1.82)$ & 0.61 \\
\hline GG & 16 & 9.70 & 13 & 7.88 & 0.61 & 0.74 & 0.56 & $1.33(0.56-3.23)$ & 0.48 \\
\hline $\mathrm{AG}+\mathrm{GG}$ & 91 & 55.15 & 85 & 51.52 & & & & $1.16(0.73-1.83)$ & 0.51 \\
\hline
\end{tabular}

${ }^{1}$ Adjusted for age, age at first sexual intercourse, and HPV-16 or -18 infection. HWE $=$ Hardy-Weinberg equilibrium, $\mathrm{OR}=$ odds ratio, $\mathrm{CI}=$ confidence interval.

\section{DISCUSSION}

In our study, we assessed the role of $I L-10-592 \mathrm{~A} / \mathrm{C},-819 \mathrm{C} / \mathrm{T}$, and $-1082 \mathrm{~A} / \mathrm{G}$ polymorphisms in cervical cancer risk, finding that the $-819 \mathrm{C} / \mathrm{T}$ genetic variation contributes to development of this disease in a Chinese population.

Previous studies have examined associations between the $I L-10-592 \mathrm{~A} / \mathrm{C},-819 \mathrm{C} / \mathrm{T}$, and $-1082 \mathrm{~A} / \mathrm{G}$ polymorphisms and several conditions related to inflammation, including deep venous thrombosis, chronic hepatitis B virus infection, sepsis, Helicobacter pylori infection, valvular calcification, and peptic ulcer diseases (Tang et al., 2014; Tunçbilek, 2014; An et al., 2015; Miftahussurur and Yamaoka, 2015; Pan et al., 2015; Ramis et al., 2015). For instance, Tang et al. (2014) carried out an investigation of 660 deep venous thrombosis patients and 660 control subjects, from which they found that the $I L-10-1082 \mathrm{~A} / \mathrm{G}$ polymorphism is associated with risk of this disease among Chinese individuals. Tunçbilek (2014) revealed that sequence variations in this same gene are involved in different clinical presentations of $\mathrm{HBV}$ infection, while Pan et al. (2015) conducted a meta-analysis indicating that $I L-10-592 \mathrm{~A} / \mathrm{C}$ and $-1082 \mathrm{~A} /$

Genetics and Molecular Research 15 (3): gmr.15038116 
G polymorphisms can affect susceptibility to sepsis. Ramis et al. (2015) failed to identify a significant association between $I L-10$ gene variants and $H$. pylori infection; however, An et al. (2015) reported that $I L-10-592 \mathrm{~A} / \mathrm{C}$ and $-819 \mathrm{C} / \mathrm{T}$ polymorphisms can influence valvular calcification risk in Han and Kazak populations. Finally, Miftahussurur and Yamaoka (2015) found no significant association between $I L-10$ genetic variations and peptic ulcer disease.

To date, several studies have assessed the association between $I L-10$ gene polymorphisms and development of cervical cancer, but with inconclusive results (Roh et al., 2002; Singh et al., 2009; Matsumoto et al., 2010; Wang et al., 2011; Barbisan et al., 2012; Chagas et al., 2013; Zidi et al., 2015). Matsumoto et al. (2010) and Chagas et al. (2013) reported that the $I L-10-1082$ variant locus may contribute to cervical cancer development in Japanese and Brazilian populations. In contrast, four other case-control studies failed to establish an association between $I L-10$ polymorphisms and susceptibility to this disease (Roh et al., 2002; Singh et al., 2009; Wang et al., 2011; Barbisan et al., 2012). However, Zidi et al. (2015) conducted a study of Tunisian patients, concluding that variations in this gene may contribute to cervical oncogenesis, while in our investigation, we observed that the $-819 \mathrm{C} / \mathrm{T}$ polymorphism in $I L-10$ may affect cervical cancer risk. The discrepancy between these results may be due to the differences caused by ethnicity, or sample-size effects. Further studies are greatly needed to confirm our findings.

In conclusion, our study suggests that the $I L-10-819 \mathrm{C} / \mathrm{T}$ genetic variation may contribute to cervical cancer risk in the Chinese population under investigation, but no such association was observed in relation to the $-592 \mathrm{~A} / \mathrm{C}$ and $-1082 \mathrm{~A} / \mathrm{G}$ polymorphisms.

\section{Conflicts of interest}

The authors declare no conflict of interest.

\section{ACKNOWLEDGMENTS}

We thank the great help of staffs from the Affiliated Hospital of Yanan University and Affiliated Hospital of Yanan University by performing the interview of the included subjects.

\section{REFERENCES}

An Y, Wang YT, Ma YT, Wulasihan M, et al. (2015). IL-10 genetic polymorphisms were associated with valvular calcification in Han, Uygur and Kazak populations in Xinjiang, China. PLoS One 10: e0128965. http://dx.doi. org/10.1371/journal.pone.0128965

Barbisan G, Pérez LO, Contreras A and Golijow CD (2012). TNF- $\alpha$ and $I L-10$ promoter polymorphisms, HPV infection, and cervical cancer risk. Tumour Biol. 33: 1549-1556.http://dx.doi.org/10.1007/s13277-012-0408-1

Chagas BS, Gurgel AP, da Cruz HL, Amaral CM, et al. (2013). An interleukin-10 gene polymorphism associated with the development of cervical lesions in women infected with Human Papillomavirus and using oral contraceptives. Infect. Genet. Evol. 19: 32-37.http://dx.doi.org/10.1016/j.meegid.2013.06.016

Chen Y, Liu X, Chen M, Shen J, et al. (2015). CD192 gene variant and susceptibility to cervical cancer: a meta analysis. Int. J. Clin. Exp. Med. 8: 9341-9347.

D’Andrea A, Aste-Amezaga M, Valiante NM, Ma X, et al. (1993). Interleukin 10 (IL-10) inhibits human lymphocyte interferon gamma-production by suppressing natural killer cell stimulatory factor/IL-12 synthesis in accessory cells. J. Exp. Med. 178: 1041-1048. http://dx.doi.org/10.1084/jem.178.3.1041

Duenas-Gonzalez A, Serrano-Olvera A, Cetina L and Coronel J (2014). New molecular targets against cervical cancer. Int. J. Womens Health 6: 1023-1031.Liang Y, Sun R, Li L, Yuan F, et al. (2015). A functional polymorphism in the promoter of MiR-143/145 is associated with the risk of cervical squamous cell carcinoma in Chinese women: A casecontrol study. Medicine (Baltimore) 94: e1289.

Genetics and Molecular Research 15 (3): gmr.15038116 
Matsumoto K, Oki A, Satoh T, Okada S, et al. (2010). Interleukin-10 -1082 gene polymorphism and susceptibility to cervical cancer among Japanese women. Jpn. J. Clin. Oncol. 40: 1113-1116. http://dx.doi.org/10.1093/jico/hyq094

Memiah P, Makokha V, Mbuthia W, Kiiru GW, et al. (2015). Epidemiology of cervical squamous intraepithelial lesions in HIV infected women in Kenya: a cross-sectional study. Afr. J. Reprod. Health 19: 133-139.

Miftahussurur M and Yamaoka Y (2015). Helicobacter pylori virulence genes and host genetic polymorphisms as risk factors for peptic ulcer disease. Expert Rev. Gastroenterol. Hepatol. 9: 1535-1547. http://dx.doi.org/10.1586/17474 $\underline{124.2015 .1095089}$

Pan W, Zhang AQ, Yue CL, Gao JW, et al. (2015). Association between interleukin-10 polymorphisms and sepsis: a metaanalysis. Epidemiol. Infect. 143: 366-375. http://dx.doi.org/10.1017/S0950268814000703

Ramis IB, Vianna JS, Gonçalves CV, von Groll A, et al. (2015). Polymorphisms of the $I L-6, I L-8$ and $I L-10$ genes and the risk of gastric pathology in patients infected with Helicobacter pylori. J. Microbiol. Immunol. Infect. S16841182(15)00721-5.

Rigaud EG (2015). Human Papillomavirus: Not just a woman's concern. Urol. Nurs. 35: 139-142.

Roh JW, Kim MH, Seo SS, Kim SH, et al. (2002). Interleukin-10 promoter polymorphisms and cervical cancer risk in Korean women. Cancer Lett. 184: 57-63.http://dx.doi.org/10.1016/S0304-3835(02)00193-3

Siegel R, Naishadham D and Jemal A (2012). Cancer statistics, 2012. CA Cancer J. Clin. 62: 10-29. http://dx.doi. org/10.3322/caac.20138

Singh H, Jain M, Sachan R and Mittal B (2009). Association of TNFA (-308G $>$ A) and $I L-10$ (-819C $>$ T) promoter polymorphisms with risk of cervical cancer. Int. J. Gynecol. Cancer 19: 1190-1194. http://dx.doi.org/10.1111/ IGC.0b013e3181a3a3af

Tang B, Chen YK, Luo WJ, Fu J, et al. (2014). Association between interleukin-10 -1082A/G, -819C/T and -592C/ A polymorphisms with deep venous thrombosis. Hum. Immunol. 75: 203-207. http://dx.doi.org/10.1016/j. humimm.2013.12.013

Torres-Poveda K, Burguete-García AI, Cruz M, Martínez-Nava GA, et al. (2012). The SNP at -592 of human IL-10 gene is associated with serum IL-10 levels and increased risk for human papillomavirus cervical lesion development. Infect. Agent. Cancer 7: 32. http://dx.doi.org/10.1186/1750-9378-7-32

Tunçbilek S (2014). Relationship between cytokine gene polymorphisms and chronic hepatitis B virus infection. World $J$. Gastroenterol. 20: 6226-6235.http://dx.doi.org/10.3748/wjg.v20.i20.6226

Turner DM, Williams DM, Sankaran D, Lazarus M, et al. (1997). An investigation of polymorphism in the interleukin-10 gene promoter. Eur. J. Immunogenet. 24: 1-8. http://dx.doi.org/10.1111/j.1365-2370.1997.tb00001.x

Wang Q, Zhang C, Walayat S, Chen HW, et al. (2011). Association between cytokine gene polymorphisms and cervical cancer in a Chinese population. Eur. J. Obstet. Gynecol. Reprod. Biol. 158: 330-333. http://dx.doi.org/10.1016/j. ejogrb.2011.05.019

Woodman CB, Collins S, Winter H, Bailey A, et al. (2001). Natural history of cervical human papillomavirus infection in young women: a longitudinal cohort study. Lancet 357: 1831-1836. http://dx.doi.org/10.1016/S0140-6736(00)04956-4

Xie B, Zhang Z, Wang H, Chen Z, et al. (2015). Genetic polymorphisms in MMP 2, 3, 7, and 9 genes and the susceptibility and clinical outcome of cervical cancer in a Chinese Han population. Tumour Biol. 10.1007/s13277-015-4204-6.

Yin G, Zhu T, Li J, Wu A, et al. (2015). CXCL12 rs266085 and TNF- $\alpha$ rs1799724 polymorphisms and susceptibility to cervical cancer in a Chinese population. Int. J. Clin. Exp. Pathol. 8: 5768-5774.

Zhang X, He R, Ren F, Tang R, et al. (2015). Association of miR-146a rs2910164 polymorphism with squamous cell carcinoma risk: a meta-analysis. J. BUON 20: 829-841.

Zidi S, Gazouani E, Stayoussef M, Mezlini A, et al. (2015). IL-10 gene promoter and intron polymorphisms as genetic biomarkers of cervical cancer susceptibility among Tunisians. Cytokine 76: 343-347. http://dx.doi.org/10.1016/j. cyto.2015.05.028

Genetics and Molecular Research 15 (3): gmr.15038116 